\title{
The financial crisis in the eurozone: a balance-of-payments crisis with a single currency?
}

\author{
Eladio Febrero* \\ Department of Economics and Finance, University of Castilla-La Mancha, Cuenca, Spain \\ Jorge Uxó \\ Department of Economics and Finance, University of Castilla-La Mancha, Talavera de la Reina, Spain
}

Fernando Bermejo

Department of Economics and Finance, University of Castilla-La Mancha, Cuenca, Spain

In a pegged exchange-rate system, a balance-of-payments crisis happens when there is serious mistrust of whether a debtor country holds sufficient international reserves to monetise a capital withdrawal at the ongoing exchange-rate parity. In the eurozone (EZ), doubts that banks and governments of peripheral countries could settle debts when they matured led to a massive capital outflow after the fall of Lehman Brothers and, especially, the first Greek sovereign-debt crisis. This has led some authors to hold that the situation in the EZ is a balance-of-payments (BoP) crisis.

However, the European Central Bank (ECB) offset massive financial capital withdrawals with a huge inflow of reserves to the EZ periphery, making the international reserves constraint irrelevant. This invalidated the BoP view in other authors' opinion, who pointed out bad bank behaviour and a poor initial institutional design as the alternative root cause for the current mess. This position is known as the monetary sovereign (MS) view.

In this paper, we provide a brief overview of the debate between both sides, with Cesaratto, as a representative for the BoP view, and Lavoie, De Grauwe and Wray, for the MS view, and discuss whether a reconciliation between these two positions can be possible. We step into the discussion to offer two additional arguments in favour of the second view: (i) A currency union requires a single monetary policy, as opposed to a fixed exchange-rate regime; TARGET2 balances combined with refinancing operations are an essential ingredient of monetary policy implementation. (ii) The current situation is more easily understood as another episode of financial instability after banks have granted huge amounts of credit (which they refinanced abroad). The situation got even worse because governments supporting troubled banks in their respective jurisdictions lacked a lender of last resort.

Keywords: eurozone, balance-of-payments crisis, monetary sovereignty, TARGET2, gross capital flows, financial instability

JEL codes: $E 12, E 42, E 58, F 32, F 34, F 36$

* Corresponding author: email: eladio.febrero@uclm.es. The authors gratefully acknowledge comments from Pedro Leão, Óscar Dejuán and two anonymous referees. The usual disclaimer applies. 


\section{INTRODUCTION}

Is the eurozone (EZ) experiencing a balance-of-payments (BoP) crisis? What has been the role played by the TARGET2 system, combined with refinancing operations provided by the European Central Bank (ECB)? What makes the difference, if any, between a currency union and a fixed exchange-rate regime? These questions are at the centre of this paper, whose main aim is to come to grips with the debate on what are the root causes of the EZ crisis: a BoP problem or something else?

Several economists from different theoretical backgrounds (see for instance Baldwin and Giavazzi 2015) hold that there is a BoP crisis in the EZ caused by excessive cross-border borrowing and lending amongst EZ countries to fund current-account imbalances, followed by a sudden stop once a crisis of confidence hit investors. Governments of debtor countries had to be bailed out as their debt became unsustainable, often after transforming private debt into public debt, because neither devaluation nor the monetisation of debt by central banks were an option. The existence of a payment system in the EZ, the so-called TARGET2 system (T2), allowed GIIPS (acronym for Greece, Ireland, Italy, Portugal and Spain) to delay the adoption of painful measures to rebalance their external sector. However, T2 imbalances have been considered an unstable and transitory solution to the current mess and peripheral countries have had to implement fiscal consolidation and internal devaluation, in exchange for additional financial assistance. T2 imbalances are widely viewed as a stealth bailout by the ECB to troubled countries, which end up in real resource transfers from surplus to deficit countries.

This BoP view has been challenged by a minority of authors. They offer, in essence, three arguments against this standpoint: the existence of the T2 combined with refinancing operations $(\mathrm{RO})$ invalidates the main requisite for a $\mathrm{BoP}$ crisis, so there is no limit for international reserves; the divorce between monetary and fiscal authorities, so that the latter miss an unconditional lender of last resort to at least stabilize their respective economies; and oversized national financial sectors that had granted too much credit before governments in their respective jurisdictions had to rescue them. This position has been defended by, amongst others, De Grauwe, Lavoie and Wray. It is familiarly known as the monetary sovereignty (MS) view or the flawed monetary union view.

We find the MS view more coherent than the BoP view. In this paper, we investigate the intricacies relating $\mathrm{T} 2$ imbalances and $\mathrm{RO}$ in the frame of the implementation of monetary policy, reaching the conclusion that the ECB had no alternative but to lend to banks when the interbank money market got fragmented and some segments had collapsed. We also provide some evidence that the root cause of the current mess is in national financial systems, that had to be rescued by their respective indebted-to-banks governments (especially in Ireland and Spain) after they got oversized, because of a lack of regulation and supervision. It was this deadly embrace between governments and banking industries without the consent of the ECB that explains more clearly what has happened in the last decade or so.

This paper is organised as follows. In Section 2, we briefly review Cesaratto's view (Cesaratto 2013; 2015a; 2015b) as a representative of the BoP view. Our decision to focus on his position is because his theoretical background is similar to that of Lavoie and Wray (that is, he accepts the endogenous money view - for example, Moore 1988 and Graziani 2003 - and also the Keynesian principle of effective demand - Keynes 1936). Next, Section 3 outlines the main tenets of the monetary sovereignty view. In Section 4, we speculate whether both views can be reconciled. Section 5 gathers two arguments against the BoP view and, hopefully, reinforces the MS view: first, T2 balances and RO are essential ingredients of monetary policy implementation, 
which are unique and the same for all members in a currency area, contrary to a fixed exchange-rate regime; and, second, the origin of the crisis is in a deregulated and badly supervised financial sector that ended up being too big, with its evolution usually related to real-estate activities, and that, in its fall, it dragged down the respective national governments. The first argument is a critique of Cesaratto's position on the $\mathrm{T} 2$ and the RO mechanism (T2-RO henceforth), whilst the second one is more focused on the so-called consensus view (see, for instance, contributions collected in Baldwin and Giavazzi 2015). Finally, Section 6 concludes.

\section{CESARATTO'S BALANCE-OF-PAYMENTS VIEW}

Cesaratto $(2013 ; 2015 a ; 2015 b)$ holds that the crisis in the EZ can be understood as a BoP crisis. His arguments can be gathered into three strands.

In the first place, he argues that the crisis in the EZ fits the following stylised facts of a BoP view. First, with the launch of the euro, we find a highly deregulated financial sector, a liberalised external sector and a strong commitment to keep the exchange rate unaltered. Second, there is a high GDP growth rate in the EZ periphery (Greece, Ireland, Spain), growing indebtedness (private in Ireland and Spain, public in Greece and also in Portugal), and large capital inflows in search of higher profitability. Third, wages grow faster than productivity and then inflation grows relatively more in the periphery, especially in the non-tradable sector, including some asset bubbles; this reinforces capital inflows. Inflation also causes, together with a rising GDP growth rate, a trade deficit which for a certain period of time is offset by capital inflows. Fourth, sooner or later, the current-account deficit outstrips the surplus in the financial-account balance, so some problems in the BoP come to the surface. Investors begin to undo some positions, and capital inflows slow down because arbitrage opportunities disappear, the financial position of domestic borrowers becomes more fragile and/or because of the risk of returning to former currencies. This leads to some fears that the monetisation of financial investments might happen at the expense of capital losses. This unleashes a massive capital outflow in search of a safer harbour.

The analogy with a financial crisis in emerging countries is rather apt, at least in the expansionary phase (Frenkel 2012). In the contractionary phase, as we will see below, there are also some similitudes although the existence of the T2 system is the source of some differences.

The second argument providing support for the BoP view is that external financial assistance, provided either by the Troika or the European Stability Mechanism, is considered quite similar to that usually provided by the International Monetary Fund (IMF) in the past to emerging countries during a financial crisis. The conditionality under which the financial assistance is given has a double justification. On the one hand - wrongly, according to Cesaratto - as expected in the Washington Consensus and the efficient market hypothesis, sound finance and liberalised markets will be expansionary in the long run although the short-term effects might be detrimental to economic growth. And on the other hand, fiscal consolidation-cum-wage deflation will restore external balance in those economies. This is a necessary condition to settle debts in a flawed, incomplete monetary union which does not have fiscal transfer mechanisms and a single bank resolution mechanism. Cesaratto adds another argument: moral hazard. Without conditionality peripheral countries could continue living beyond their means, increasing unilaterally their indebtedness to the core EZ countries with the T2-RO mechanism, as stated below, if they remained within the euro. 
The third argument is that, despite there being a single currency in the EZ, it can be viewed as a group of countries whose currencies are connected by a fixed exchange regime. This is justified on the basis that, as an alternative to the austerity measures, in principle, troubled EZ countries could always opt for abandoning the euro, devaluing their currency and recovering monetary and fiscal autonomy. And this 'convertibility risk' (to use apt words by Draghi 2012) is causing bond yield spreads to increase with regard to the German bund.

However, there is an element which is rather alien to a $\mathrm{BoP}$ crisis within the EZ experience: the T2 system, the automatic settlement system within the EZ. When someone wishes to transfer a deposit from a Spanish bank (for example, Banco Santander) to a German bank (Deutsche Bank, DB), Banco Santander orders the Banco de España to transfer her reserves to DB. Briefly, and omitting some details, at the end of the day the Banco de España assumes a liability to the T2 system when it debits the reserve account held by Banco Santander at the Central Bank of Spain. Simultaneously, the Bundesbank acquires a claim against the T2 system whilst it credits the reserve account of the DB. When the DB sees the balance of its account at the Bundesbank increase, it credits the deposit of the transfer recipient. ${ }^{1}$

In a second stage, the ECB replenishes the reserves that Banco Santander had lost before, through a main refinancing operation (MRO) or a long-term refinancing operation (LTRO), which the DB is not willing to lend in the interbank money market.

The existence of T2 makes the evolution of the BoP crisis in the EZ different from what happens in emerging countries, because in the former countries international reserves never get exhausted. This mechanism - and on this Cesaratto agrees with Sinn (2011) - is a stealth bailout of the ECB to peripheral EZ countries, because through it banks settled in the deficit countries obtain the necessary reserves to monetise the capital withdrawal which happens in a BoP crisis. Hence, they can delay the adoption of painful measures to rebalance their external sector and they could keep on running current-account deficits, or refinancing outstanding debt without any limit. ${ }^{2}$

Notwithstanding this, although T2 delays the consequences of a BoP crisis, it does not stop it. As Cesaratto (2015b, p. 16) states:

In theory the [T2] system could continue indefinitely. However, faced with a lack of any peripheral foreign rebalancing perspective and mounting [T2] imbalances, what actually happened in Europe was a sort of political halt to current account imbalances calling for correction through austerity measures. ... ECB support was intolerable for core countries without continuation of austerity measures in order to avoid any moral hazard incurred by peripheral countries that could otherwise rely on [T2] and refinancing operations to endlessly increase their foreign imbalances. ${ }^{3}$

1. Some relevant aspects of $\mathrm{T} 2$ balances are: they are unlimited and do not prescribe; debtors to T2 have to pay the official interest rate to the system; T2 liabilities are not bilateral (that is, in our example, the Banco de España is not indebted to the Bundesbank, but to all the owners of the ECB according to their capital pro rata).

2. As Garber (2010) notes, and Cesaratto reiterates, banks in the periphery could grant new credit to agents already indebted to the rest of the EZ, and the corresponding deposits (newly created as endogenous money theorists hold) could be used to repay maturing debts that international creditors do not wish to roll over, through the combination of T2 and RO. See below. 3. An additional reason to complain about increasing $\mathrm{T} 2$ imbalances is that, in the event that banks in the EZ periphery default, they would not repay either principal or interest on refinancing loans to their central banks; hence, the central banks in the core would make a loss as well. 
The Italian author also argues that in a viable monetary union (see Barba and De Vivo 2013 for an explanation of the concepts of viable and flawed monetary unions), including sizable fiscal transfer mechanisms, external trade imbalances could find a financial compensation and, therefore, a BoP crisis could be avoided. However, this idea is a chimera because Germany fully rejects the abandonment of her neo-mercantilist model and the public opinion in the core countries does not welcome solidarity measures for the periphery.

Finally, the economic policy recommendation which can be drawn from this interpretation of the EZ crisis is that, without any hope that a banking, fiscal and finally political union will be reached soon, it is better for countries that cannot keep apace on productivity and inflation with Germany and other core EZ countries to leave the euro and recover autonomy to manage fiscal, monetary and exchange-rate policies.

\section{THE MONETARY SOVEREIGNTY VIEW}

There are three main arguments supporting this view: (i) the existence of the T2 system, which means the irrevocable shift from a pegged exchange-rate system to a unique currency; (ii) the divorce between monetary and fiscal authorities; and (iii) financialisation or money manager capitalism, which shifts the origin of the crisis from profligate agents to a slow transformation of the capitalist system, where finances play an increasingly relevant role. With due caution, we link the first argument to Lavoie, whilst the second one is usually connected to De Grauwe, ${ }^{4}$ and Wray is a representative of the third.

In Lavoie (2015a), the Canadian author compared the T2 system with Keynes's plan for an International Currency Union (Keynes 1942 [1969]), ${ }^{5}$ reaching the conclusion that the crisis in the EZ was not due to BoP constraints, but rather a banking crisis which transformed itself into a public debt problem (ibid., p. 10).

In his response to Cesaratto (2015a), Lavoie (2015b) rejected the BoP view quite persuasively: a BoP crisis requires the fulfilment of four requirements: (a) a country experiences a massive financial capital withdrawal; (b) its holdings of international reserves present a limit for said withdrawal; (c) its holdings of international reserves become exhausted; and (d) the country has to adopt a contractionary adjustment (fiscal consolidation, wage deflation, debt default and debt restructuring) with a view to shifting its economy towards a balanced or surplus external position. Peripheral EZ countries have experienced (a) and (d) but neither (b) nor (c), because of the existence of the T2 system. And (d) - particularly, fiscal consolidation and internal devaluation through wage deflation - has been experienced not because peripheral countries have outstripped any hypothetical threshold of indebtedness to core EZ countries after having lived beyond their means, but as a consequence of self-imposed restrictions on the ECB to act as buyer of last resort of public debt.

Regarding points (b) and (c) mentioned above, Lavoie holds that the mere existence of the T2 system makes the BoP view simply wrong, because the holding of international reserves is no longer a relevant constraint within the EZ: capital outflows automatically lead to T2 imbalances. And these imbalances are unlimited, uncollateralised

4. Notwithstanding this, many post-Keynesian authors had already warned of real problems caused by the divorce between fiscal and monetary authorities. See for instance Parguez (1999, pp. 93-95) or Kelton and Wray (2009).

5. See also Cesaratto (2013, p. 369). 
and can be rolled over as many times as needed. ${ }^{6}$ Furthermore, T2 imbalances can monetise capital reversals and also newly created external imbalances, in the sense that if peripheral banks are able to provide resident agents with fresh finance (initial finance) to fund current-account deficits, the transfer of reserves through the T2 system to exporting countries will lead to final finance, which then may or may not be lent to the bank in the peripheral EZ country in the form of an overnight loan.

Of course, Lavoie realises that T2 is not the solution for all the problems in the EZ: banks granting too much credit may become insolvent, leading to huge losses for equity holders and depositors, and, again, an excessive public debt without the support of a central bank may cause big losses for its holders but, all in all, we are not dealing with a BoP crisis.

The second argument, complementary to the T2 case, which justifies why there is not a BoP crisis in the EZ, turns around the notion of the divorce between the central bank and national fiscal authorities. In a nutshell, the argument is that governments need a lender of last resort in much the same way private banks do. As De Grauwe (2013) has put it, there are two reasons for this. First, because of the need to stabilise an unstable economy through automatic stabilisers without the fear of a budget deficit ending up as a self-fulfilling insolvency crisis. And second, to break the doom loop between banks and fiscal authorities once a banking crisis occurs and the fiscal authority has to rescue them.

In the absence of a central bank able and willing to play the role of buyer of last resort of public debt, fiscal authorities running budget deficits may experience a shift from a liquidity problem to a solvency problem, dragging along banks burdened with sovereign debt, if financial markets strongly believe that sovereigns are unable to return to sound finances. That is what happened to peripheral EZ countries (see for instance De Grauwe and Ji 2013). The endeavour to rebalance the public budget simply worsens the situation. This leads De Grauwe (2013, pp. 26ff) to reject the argument of a BoP crisis as well.

The third argument mentioned above points to an alternative interpretation of the origin of the current financial crisis. The increasing relevance of finances in corporations' profitability, income distribution shifts in favour of profits, and the weakening of the corporate profits-productive investment channel had made advanced market economies more and more dependent on bank debt, especially household debt (Turner 2016 calls this wrong debt; see ch. 4). Wray (2012a) points to a banking crisis, once indebtedness becomes unsustainable, as the initial cause of the crisis in the EZ: "Any EMU nation can be blown up by its banks even while running a current account surplus ... . This is the "financialisation" or "Money Manager Capitalism" story that comes from Hyman Minsky'. The divorce between fiscal and monetary authorities, or chronic current-account imbalances, were amplifiers of the crisis. A great deal of cross-border borrowing before the global financial crisis was not recorded in financial accounts (see for instance Borio and Disyatat 2015). ${ }^{7}$ Growing bank balance sheets was possible

6. It should be noted that when investors transferred their funds from the periphery to the core EZ countries, they exchanged risk-free central-bank reserves for risky assets at no cost (Dullien and Shieritz 2012). Further, the risk implicit in the refinancing loans that go hand-in-hand with T2 imbalances mean no loss for the European System of Central Banks since their liabilities are not covered by their assets (for example, De Grauwe and Ji 2013).

7. According to data provided by the ECB, at the end of 2007, Irish gross external debt in absolute levels was roughly the same as Spanish gross external debt, and barely 12 per cent less than that found in Italy. However, its GDP was 18 per cent and 12 per cent of Spain and Italy's. Irish monetary and financial institutions had accumulated a gross external debt of around 400 per cent of GDP at that time, half of total gross external debt. 
because of a lack of regulation and supervision and because the removal of barriers to the circulation of capital allowed banks to buy assets and issue liabilities - often related to speculative operations - across the whole EZ. When those operations went bad, national governments had to bail them out.

The recommendations for economic policy which can be drawn from this standpoint are that the EZ should increase its degree of integration, towards an economic, fiscal, banking and ultimately political union. Fiscal harmonisation and transfers, and a unique guarantor of bank deposits, appear to be key elements for dealing with the crisis. If these are not possible, troubled countries might seriously think about abandoning the euro. ${ }^{8}$ In any event, downsizing, regulating and supervising the financial sector across the EZ are essential ingredients for a return to stability and growth.

\section{IS A RECONCILIATION BETWEEN THE BoP AND THE MONETARY SOVEREIGNTY VIEW POSSIBLE?}

Some authors have pointed out that the BoP and the monetary sovereignty view might not be so far from each other and that any differences are based on minor details. We find three positions. First, that there is a BoP in the EZ, but only in the expansionary phase, when peripheral EZ countries grow, accumulating a number of imbalances (Cesaratto 2015b informs on this view). Second, the BoP view holds because the EZ lacks the mechanisms, existing in stand-alone countries, to restore the equilibrium in troubled countries: in essence, a supranational fiscal authority able to make transfers amongst regions and a centralised bank resolution mechanism. If these mechanisms were present in the EZ we would not be talking about a BoP crisis (Vernengo 2015). Finally, there is some degree of subjectivity as to whether the EZ can be viewed as a currency union or as a group of countries whose currencies are tied together by a fixed exchange rate. If the second case is acceptable (Cesaratto 2013 considers that the $\mathrm{EZ}$ is closer to a fixed exchange-rate regime, because it is a flawed currency union), the EZ has suffered a BoP crisis.

Cesaratto (2015c) rejects any possibility of reconciliation, arguing that a sudden stop took place in the EZ in 2012, and that there is a certain debt threshold which, if trespassed, thus incurring a moral hazard, leads to creditor countries imposing restrictions on debtors, fiscal austerity and internal devaluation.

In our view, MS supporters would agree with Cesaratto that reconciliation is impossible, but only because what happens in the EZ is simply a financial instability problem, since governments do not have a lender of last resort. The irrelevance of the international reserves constraint invalidates the BoP view.

\section{TWO ARGUMENTS AGAINST THE BoP VIEW}

We delve now into greater detail on two issues regarding this debate which, in our opinion, shift the balance towards the MS view. Why does the central bank lend reserves to banks that lose deposits in a monetary union? And what has been the main impetus for external debt in EZ countries, whether current-account imbalances or gross capital (in-)flows to banks?

8. On this issue, see Heise (2015). 


\subsection{The T2-RO mechanism and the single currency}

Cesaratto (2013) and Lavoie (2015a) find similarities between Keynes's plan for an International Currency Union (ICU) and the T2 system. In both cases, when a cross-border bank deposit transfer is made, as a payment or for whatever reason, the central bank of the country where the deposit is withdrawn acquires a liability to a supranational bank (the ECB that manages the T2 system, or the International Clearing Bank, hereafter the ICB) and simultaneously provides an advance to the commercial bank in its jurisdiction. At the same time, the central bank in the recipient country acquires a claim on the supranational bank and credits the recipient bank account at the central bank. ${ }^{9}$

However, there is a remarkable difference between both systems. The ICU is conceived as a payment mechanism that helps to keep afloat a fixed exchange-rate regime. Conversely, the T2, which is a payment system as well, works in a single currency area where exchange-rate markets simply do not exist. ${ }^{10}$ Why, then, does the ECB lend reserves to deficit countries? The answer, in our opinion, is that the T2, combined with RO by the Eurosystem) is an essential ingredient for maintaining control over the overnight interest rate, the instrument by means of which a central bank implements its monetary policy. ${ }^{11}$ In a single currency area, contrary to a fixed exchange-rate regime, a main distinguishing feature is that there is a single central bank implementing a single monetary policy across the whole territory. Monetary policy, as is widely accepted, is conducted through the management of the interest rate. In order to do so, once that level has been set, the central bank has to make it possible for banks to comply with the reserve requirements, intervening if necessary in the interbank money market to keep the overnight interest rate close to its target level (see for instance Bindseil 2004 or Lavoie 2014, ch. 4).

In the market for reserves, the demand can be conceived as a function of deposits held by banks whilst the supply of reserves is the item on the central-bank balance sheet that equalises the sum of assets and liabilities. Three groups of items can be distinguished on a central-bank balance sheet: autonomous liquidity factors, monetary policy operations and reserves (for example, Bindseil 2004, p. 48). When the central bank faces a change in an autonomous liquidity factor (which includes all items that do not reflect monetary policy operations or reserve holdings: ibid., p. 46), the supply of reserves changes pari passu. Consequently, the overnight interest rate changes because of the mismatch between the supply and a highly inelastic demand for reserves. In symmetric corridor systems with a reserve requirement, when the supply of reserves falls, the overnight rate of interest goes to the credit facility rate, and banks as a whole must borrow from the credit facility in order to comply with the reserve requirement.

9. Tables 1 and 2 in Lavoie (2015a) clearly illustrate these issues.

10. As Garber (2010, p. 1) points out, '[the T2] irrevocably unifies the former national currencies, converting a set of currencies whose exchange rates are merely fixed at par into a single currency'.

11. Of course, this does not preclude the importance of the smooth running of the payment system as another motive for a central bank to lend reserves to commercial banks. Actually, as Bindseil and König (2012, p. 161) state: 'T2 balances are a reflex of underlying payment flows of central bank money beyond national borders'. Furthermore, an implication of the T2 as a payment mechanism is that a transaction between two agents residing in different EZ member states is on the same footing as a transaction made between two agents residing in the same country. 
In the EZ, T2 balances are not present on the ECB's balance sheet, but they are on the balance sheets of national central banks making up the European System of Central Banks, as autonomous liquidity factors (Bindseil and König 2012, p. 21). Hence, when a deposit is transferred from, for instance, Banco Santander in Spain to Deutsche Bank in Germany, the Spanish Central Bank loses reserves whilst it acquires a liability to the T2 system, and the opposite happens in Germany. ${ }^{12}$ This reflects the T2 as a payment system.

When the interbank money market became fragmented, with some segments having almost collapsed, and deposits beginning to flow from the EZ periphery to Germany, mainly after the Greek sovereign-debt crisis in May 2010, the overnight interest rate should have reached the ceiling in the periphery, and the floor in the core EZ, because of the deposit facility (see Febrero et al. 2015).

The ECB partly avoided such an outcome by introducing the so-called full allotment of reserves at a fixed rate (ECB 2011) in October 2008 as part of the enhancing credit support measures to improve the working of the interbank money market with a view to keeping bank credit flowing (see for instance Trichet 2013). This unconventional measure can be viewed as a horizontal supply of reserves in the peripheral segments of the interbank money market, matched by a vertical demand for reserves shifting to the right, which are then transferred through the T2 system to the core EZ, where we have an overnight interest rate gravitating around the deposit facility rate.

The ECB had no choice but to provide reserves to countries experiencing a massive capital outflow. Otherwise: (i) it would have lost control over the overnight interest rate; (ii) the payment system would have collapsed because deposits in euros in the periphery could not have been used as means of payment in the whole EZ; and (iii) it could not deny the provision of reserves to banks holding eligible collateral.

Notwithstanding this, the horizontal supply of reserves implicit in the full allotment of reserves poses two difficulties to the post-Keynesian Horizontalist standpoint. First, the ECB did not have control over long-term interest rates, ${ }^{13}$ and second, despite the horizontal supply of reserves, the ECB still retains some control over the amount of reserves lent to banks.

Regarding the first difficulty, since mid 2009, longer-term interest rates, ruled by national long-term bond yields, have been relatively high in peripheral EZ countries, with large spreads as compared to the German bund. As shown in Figure 1, despite the large LTROs in December 2011 and February 2012, amounting to roughly $€ 1$ trillion euros, Spain and Italy's T2 imbalances and long-term bond yield spreads with the German bund did not stop increasing until the OMTs (Outright Monetary Transactions) were announced by Draghi in July 2012 (see for instance Purificato and Astarita 2015). ${ }^{14}$

12. The reader may realise that we are breaking down the T2-RO mechanism into two steps: in a first round, the bank losing deposits also loses reserves, and in a second round, the central bank in its jurisdiction credits the bank's reserve account through a refinancing loan. T2 imbalances cause the first round change in reserves.

13. Trichet (2013) mentions three channels through which public debt affects the transmission of monetary policy: the price channel (the long-term interest rate), the balance-sheet channel (changes in the price of debt lead to changes in bank equity, when banks have large amounts of public debt in their balance sheets), and the liquidity channel (public debt is very much used as collateral in the interbank money market and in financial operations with the ECB).

14. The financial assistance provided by the European Stability Mechanism to the Spanish government, for the recapitalisation of the banking system in mid 2012 markedly contributed to the reduction of $\mathrm{T} 2$ imbalances and the bond yield. 


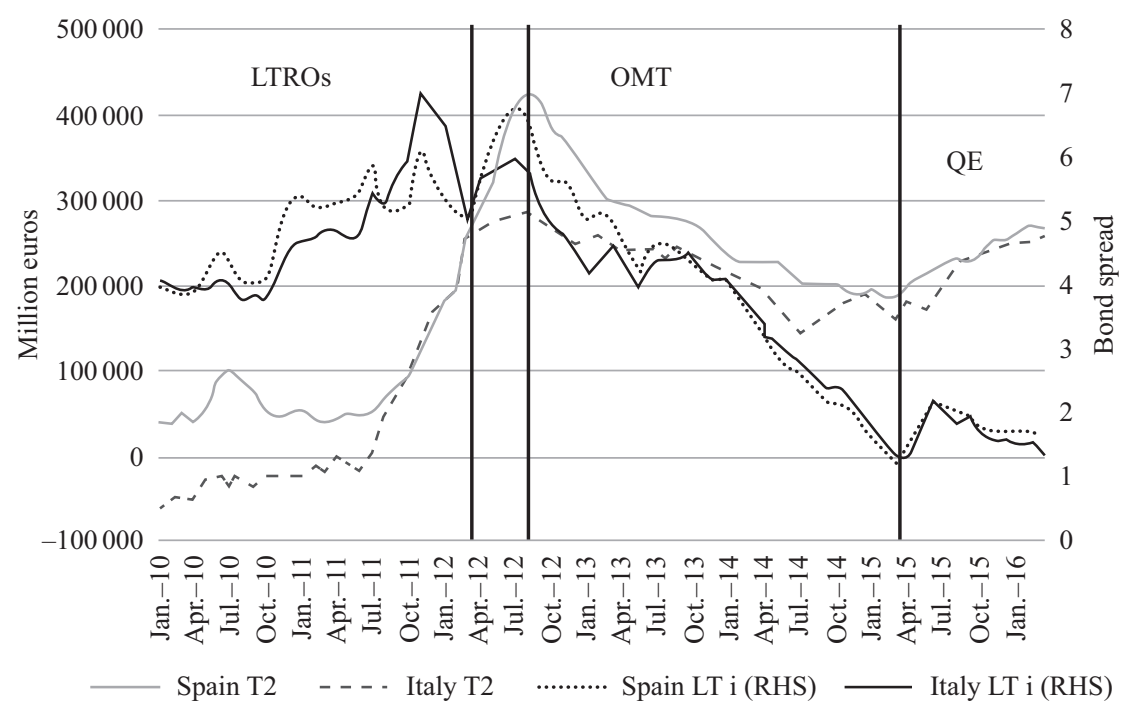

Note: $\mathrm{QE}=$ quantitative easing.

Source: Euro crisis monitor, BdE and authors' calculations.

Figure 1 T2 imbalances and ten-year bond spread with respect to the German bund, Spain and Italy, 2010-2016

This figure proves that there was not a $\mathrm{BoP}$ crisis in the EZ: the price of sovereign bonds in peripheral EZ countries began to increase, reflecting fears of default by their respective issuers, leading to more difficult access to funding in international markets for all agents in their jurisdictions. At first sight, one might think of a $\mathrm{BoP}$ crisis caused by a sudden stop, following too much cross-border debt. However, the OMTs - and the asset purchase programme in 2015 - also showed that, once the ECB threatened markets with purchasing public debt en masse, the price of bonds rose and financial markets became reactivated. Thus, the sudden stop was the consequence of governments indebted in a foreign currency (as Neochartalists have stated on several occasions) and not the cause of the crisis. ${ }^{15}$

With respect to the second difficulty mentioned above, the full allotment of reserves at a fixed rate may give rise to an unlimited provision of funds to governments, as they can force banks to create new deposits to fund the purchase of newly issued public debt that they can then use to obtain refinancing loans (Garber 2010). The ECB can avoid such a situation by deciding what collateral is acceptable in open-market operations (normally implemented through collateralised loans). Here, the ECB showed a certain degree of flexibility when it decided to shift the rating limit on public debt from A- to BBB- in October 2008 (ECB 2008), as part of the so-called 'enhanced credit support' (Trichet 2013). By contrast, on other occasions the ECB, jointly with the European Commission and the IMF, has used this measure to force national governments to adopt certain painful economic measures, avoiding a problem of moral hazard.

15. Although Cesaratto might agree with this statement, the so-called consensus view (Baldwin and Giavazzi 2015, p. 49) points to the sudden stop of capital flows after a large volume of cross-border intra-EZ borrowing and lending as the cause of the crisis in the EZ. 
The Greek experience in 2015, the so-called Grexit, clarifies this issue. In February 2015, the ECB decided to stop accepting Greek public debt as collateral in RO (see ECB 2015a). This forced Greek banks to obtain central-bank reserves through Emergency Liquidity Assistance (for details about ELA see for instance ECB 2007, p. 80, or The Economist 2015). See also Bindseil and König 2012, pp. 145 and 157). In late June 2015, the ECB refused to extend the amount of liquidity that the Central Bank of Greece could lend to Greek banks (ECB 2015b) through ELA. This meant that without the provision of reserves by the ECB to Greek banks, Greece would have been forced to leave the euro in a short period of time: despite some capital controls and bank holidays, the Greek banking system was doomed to collapse because bank deposits could no longer be used as a means of payment in the EZ; the only solution would have been a return to the drachma. And without the ECB refinancing Greek banks, the Greek government would also have defaulted on all debts maturing from mid 2015 onwards, denominated in euros (Wyplosz 2015). The Greek government ended up accepting conditions for the third bailout, avoiding default in July 2015 (European Council 2015).

In our view, the threatened Grexit does not prove the BoP view. ${ }^{16}$ Grexit was a serious Troika threat, a form of blackmail to force the Syriza government to accept the conditions linked to a third bailout, mainly needed to recapitalise banks and settle debts with the Troika. Without any possibility of Greek banks getting central-bank reserves, the ECB set Greece on a course to leave the euro within a few days, because the payment system, in euros, was going to disappear. Greece would be on the brink of a BoP crisis once it had left the euro and returned to the drachma, not before. Without any access to refinancing from the ECB, the problem for Greece was that the payment system would collapse within hours and returning to the drachma would entail a strong devaluation followed by all the economic policy measures that the Greek government was trying to avoid.

There was a strong political motive behind the decision not to accept Greek public debt as collateral and then to freeze ELA. If the ECB had rejected a reduction in quality of eligible collateral in RO from A- to BBB-in 2008, we would have been talking about a Spanexit or an Italexit since 2012, followed, very likely, by a euro break-up.

In weighing the issue with some perspective, and despite the profligacy of Greek governments, it can hardly be claimed that the Grexit was the consequence of a moral hazard problem incurred by Greeks alone. As Wyplosz (2015) has put it quite clearly, the ECB has had a great deal of responsibility in the Greek mess, rejecting a write-down of Greek debt in 2010; not to mention France and Germany, who backed the ECB with a view to protecting their large banks, which had a large exposure to Greek debt, and the IMF (see also Geithner 2014, especially ch. 11), which feared another Lehman-style crisis. The financial assistance first provided to Greece in 2010 unleashed a downward spiral of fiscal austerity - falling GDP has brought us to the current situation.

In short, a central bank can have the power to control the overnight interest rate through the infinitely elastic supply of reserves (the so-called Horizontalist standpoint) whilst simultaneously being unable to control longer rates, linked to the yield of public

16. Cesaratto does not make any explicit mention of the Grexit as an argument in favour of the BoP crisis view: his positions date back to at least 2013. However, we make this statement because the reader might think that without access to funding in euros, Greece was experiencing a BoP crisis: the requirements listed by Lavoie for a BoP crisis mentioned above hold in the Greek case. 
bonds, when there is a divorce between monetary and fiscal authorities (for example, Kelton and Wray 2009). The unrestricted supply of reserves invalidates the BoP crisis view in the EZ, because member states do not lack international reserves to make payments. Notwithstanding this, they may experience difficulties for funding in international markets when the creditworthiness of the government is doubtful. This harder access to market funding is explained by the self-inflicted rule that prohibits the ECB from purchasing public debt from national treasuries. The ECB can even cut the access to reserves. However, this is more a measure to press a government to adopt some painful measures than proof of a BoP crisis.

\subsection{Current-account imbalances or too much bank credit? ${ }^{17}$}

Gros (2015) writes: 'No country which had in 2008 a current-account surplus and/or a positive net external asset position had to endure lasting financial stress - irrespective of the level of its public debt'. This author holds that the origin of the current situation in the $\mathrm{EZ}$ is a BoP crisis, because of a sudden stop to capital flows after a large volume of lending and borrowing among EZ member states, driven by excessively large current-account deficits (CAD), over a long period of time. ${ }^{18}$ This account stands in contrast to the MS view (particularly Wray 2012a; 2012b) which holds that the cause of the crisis is too much bank credit refinanced abroad by banks and an overgrown financial system and, when trying to implement counter-cyclical fiscal policies and rescue their respective banking industries, national treasuries were dragged into a solvency crisis, placing the CAD motive in the back seat.

In our view, Gros's account contains a grain of truth (too much cross-border debt increases the exposure to a sudden stop) but it also has two difficulties. First, it is not clear whether current-account imbalances and net capital flows are major factors explaining rising external debt. Our alternative candidate is gross, not net, capital flows to banks, connected to financial activities. Second, the crisis in the EZ periphery, despite heterogeneous situations, did not find its root cause in a sudden stop of capital flows. Conversely, the debt-led growth pattern in Greece, Ireland and Spain - and to a lesser extent, Portugal (Hein 2013) - was simply unsustainable. The Irish and Spanish real-estate sectors, which had experienced a bubble since the onset of the euro, began to show some weakness in 2005; the global financial crisis that followed the fall of Lehman Brothers simply aggravated the situation in 2008-2009 (Whelan 2013 for Ireland; Febrero and Bermejo 2013 for Spain). Later, the Greek sovereign-debt crisis made it crystal clear that the national treasuries of EZ member states were at risk of default; this fear unleashed rising bond yield spreads in countries whose public sectors' solvency was dubious. The fiscal consolidation and wage deflation that followed the first Greek crisis in May 2010 drove GIIPS countries to a second crisis wave in 2011. ${ }^{19}$

17. This section pits the MS view against the so-called consensus view (Baldwin and Giavazzi 2015) and not so much against Cesaratto's BoP view.

18. Krugman (2012) reaches a similar conclusion.

19. The (mainstream) theoretical justification for these measures was that, whilst fiscal consolidation would lead to falling long-term interest rates as investors' confidence rose, wage deflation would contribute to the recovery of competitiveness, improving net exports and helping to increase solvency. However, it goes without saying that pro-cyclical fiscal policy combined with falling wages when the population was heavily indebted did not yield the desired results: neither the public budget deficit fell, nor did GDP begin to grow again. See for instance Dodig and Herr (2014). 
Of course, these measures were adopted as a reaction to a sudden stop, followed by a reversal of capital flows in the EZ. But, contrary to Gros's consensus view, said sudden stop took place because of the ECB's unwillingness to give support to sovereign debt. As the announcement of the OMTs showed (see above), once the ECB threatened markets with the purchase of unlimited amounts of public debt, financial flows were reactivated and the price of sovereign debt fell markedly.

Although we agree with Cesaratto that moral hazard is relevant, we believe that the constraint on the ECB monetising sovereign debt in 2010-2011, despite the securities market programme, was mainly based on the belief that markets would impose sufficient discipline on profligate governments through the falling price of their public debt, whilst core EZ countries would remain unaffected. However, the valid possibility of a euro break-up (if Greece had to leave, it was highly likely that Spain and Italy might follow: see for instance Spiegel 2011) led Draghi to pronounce in July 2012 the famous words 'Within our mandate, the ECB is ready to do whatever it takes to preserve the euro. Believe me, it will be enough', and announce the OMTs.

As an alternative to $\mathrm{CAD}$, we find the oversized banking sector a good candidate as the detonator of the current mess in the EZ. We take arguments from Borio and Disyatat $(2011 ; 2015)$ in favour of the financial instability hypothesis. These authors suggest that researchers' interest should shift from net to gross capital flows as a source of external financial vulnerabilities. ${ }^{20}$ They base this recommendation on two arguments. The first one is that a country may accumulate a large volume of external debt even running a balanced current account (see also Wray 2012a; 2012b). This can be presented using formal expressions by Al-Saffar et al. (2013, p. 5):

$$
I-S=C A D=\Delta D+\Delta E .
$$

It is well known that when investment $(I)$ outstrips national savings $(S)$ we have a current-account deficit $(C A D)$ which has to be financed by issuing debt $(\triangle D)$ or equity $(\Delta E)$ - that is, with a financial account surplus. However, it may be that the current account is balanced and, simultaneously, a country borrows overseas $(\Delta D)$ and, ultimately, uses the proceeds to fund the cross-border purchase of equity $(-\Delta E)$.

Eventually, the risks of a sudden stop may become real once outstanding (gross) cross-border debt is high, if: liabilities (that is, gross inflows) and assets (gross outflows) are of a different nature (equity versus debt), assets and liabilities are held by different agents, and they are denominated in different currencies or they have different maturity (see for instance Turner 2016, ch. 9).

Ireland is a good example of this issue. As Figure 2 shows, Ireland ran currentaccount deficits for ten years between 1999 and 2013, reaching 5.42 per cent GDP in 2008, and whose accumulated sum between 1999 and 2008 amounted to a little less than 20 per cent GDP. ${ }^{21}$ However, in the same period of time, yearly gross capital inflows ranged between 116 per cent GDP and 180 per cent GDP, and the accumulated sum of gross capital inflows reached 716.58 per cent GDP. ${ }^{22}$ Hence, should we blame the current-account balance or, rather, gross capital flows for the Irish exposure to a sudden stop and the 2008-2013 crisis?

20. Similar views are held by Johnson (2009, p. 1) and Obstfeld (2012, p. 17).

21. NIIP (Net International Investment Position) was much larger because of net valuation effects (Lane 2014). Nevertheless, even taking the latter effect into account, NIIP was a little less than 100 per cent GDP in 2011.

22. The external debt for Irish monetary and financial institutions reached 400 percent of GDP in 2008, and gross external debt outstripped 1000 per cent of GDP in 2009. 


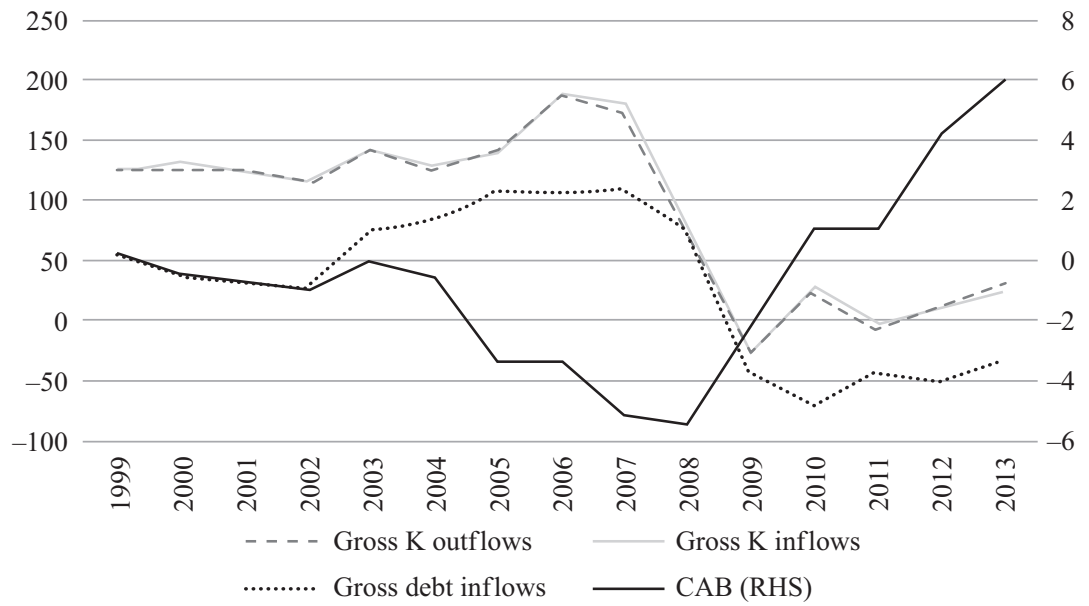

Source: CSO and authors' calculations.

Figure 2 Gross capital inflows and outflows and current-account balance, Ireland, 1999-2013 (percentage GDP)

The second argument in Borio and Disyatat is that, very often, there is a positive correlation between gross capital inflows, bank credit, asset prices and GDP growth (see for instance Al-Safar et al. 2013; Brunnermeier et al. 2012; Janus and RieraCrichton 2016; Rey 2013) and credit growth is a good predictor of financial crises (Mian and Sufi 2014; Schularick and Taylor 2012; amongst others). ${ }^{23}$

The Spanish experience illustrates this situation, as shown in Figure 3. On the one hand, there is a very high correlation between bank credit to households and nonfinancial corporations and gross capital inflows (excluding foreign direct investment in Spain and inflows to the Banco de España), amounting to 0.96 over 2001-2012. And on the other hand, gross capital inflows were much larger than current-account imbalances until 2008. Hence, the responsibility for external indebtedness should not fall on current-account deficits (although these are relevant, of course) but mainly on the bank credit boom that banks refinanced in international markets. ${ }^{24}$

The crisis in the EZ periphery, despite a heterogeneous situation, is to some extent the normal expected outcome of a protracted period of very high growth funded with

23. The intuition behind this empirical regularity is that banks refinance the loans that they make in international financial markets, after the corresponding newly created deposits flow to other resident banks. This leads to a temporary excess reserve in the country which disappears in the form of capital outflows. As Broner et al. (2013) or Rey (2013) have shown, there is a strong comovement of gross inflows and outflows, which are much more volatile than net flows. 24. Over 2002-2008, accumulated bank credit to households and non-financial corporations amounted to 108 per cent GDP, gross external debt to 92 per cent GDP and banks' gross external debt to 82 per cent GDP. Accumulated CAB deficits led to just 38 per cent GDP, a little more than one-third of gross external debt, before the real-estate bubble burst. In late 2012, accumulated $\mathrm{CAB}$ deficits since 2002 reached 55 per cent of gross external debt and this figure then declined to 45 per cent by the end of 2015. This leads us to hold that CAB deficits are important, though not the main cause of gross external debt. 


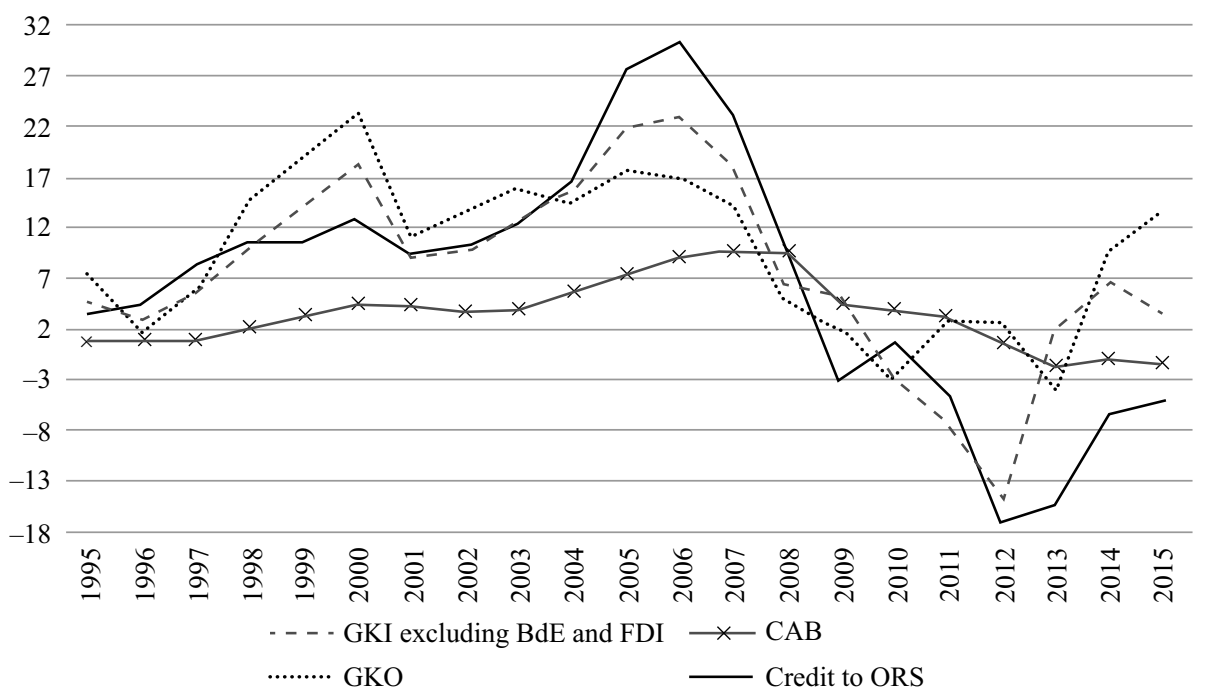

Notes: The sign for CAB has been changed: a positive value means a deficit. GKI and GKO stand for gross capital inflows and outflows, respectively. ORS stands for Other Resident Sectors (meaning households and non-financial corporations).

Source: BdE, INE and authors' calculations.

Figure 3 Gross capital flows, bank credit and current account, Spain, 1995-2015 (percentage GDP)

bank credit that banks refinanced abroad (Bellofiore et al. 2015 add a process of industrial restructuring; Hein 2013 sees it as another crisis episode in the process of financialisation; Wray 2009 and 2012c calls it money manager capitalism). Current-account deficits should be viewed as another consequence of a debt-led boom and not so much as the root cause of external imbalances. ${ }^{25}$

In short, countries with higher domestic credit growth have experienced higher than average GDP growth, with the exception of Portugal, until 2007, followed by a deeper recession, between 2008 and 2013. This has happened in the context of financialisation and money manager capitalism. Higher GDP growth has come with a loss of competitiveness and increasing current-account imbalances. This is more an effect than a cause of the boom driven by bank debt. Banks in the periphery have refinanced the credit that they granted before in international financial markets, offering an attractive yield to savings in the core. But gross capital inflows were very loosely related to current-account imbalances. And the cause of the crisis in the periphery is mostly due to the unsustainability of a debt-led growth pattern, not a BoP. The sudden stop

25. For instance, Shin (2012) coined the term 'banking glut' to describe how American banks granted mortgage loans that were then packed in securities and sold through shadow banks to European banks with funds that the latter had borrowed previously in US wholesale markets. For him, it was not the 'saving glut' (net inflows mirroring CAD) but a huge elasticity of bank credit, magnified by gross capital inflows and outflows, that caused the Great Recession. As Keister and McAndrews (2009) show, the Fed injected large amounts of reserves into the US banking industry, as the ECB did, once the interbank money market stopped working. However, what made the difference between the EZ and the US was that the US is monetarily sovereign. 
and the capital reversal observed since 2009 is the consequence of increasing risks from self-inflicted rule by means of which the ECB does not buy sovereign debt either in primary or secondary markets. Without such a safety net, it is well known that national banking industries and sovereigns can default.

\section{CONCLUSIONS}

There are two views that aim to provide an explanation of the crisis in the EZ: the BoP view and the monetary sovereignty view. We have focused on Cesaratto's view in favour of the BoP crisis because he shares the same theoretical frame as supporters of the alternative view (briefly, endogenous money and the Keynesian principle of effective demand). There are three essential elements which support this view: strong similarities with what has happened in emerging markets affected by a financial crisis, a convertibility risk, and a moral hazard problem.

In our perspective, which is sympathetic to the monetary sovereignty view, the BoP view is incorrect because of three elements: the existence of the T2-RO mechanism, the divorce between monetary and fiscal authorities, and an overgrown financial sector that dragged treasuries down as it fell. In this paper, we have argued that T2 imbalances must go hand-in-hand with RO, when the interbank money market becomes fragmented, but T2 imbalances combined with RO alone are not enough to prevent a sovereign and banking crisis: the ECB should play the role of buyer of unlimited amounts of public debt, like the OMTs, but without any conditionality.

The so-called Grexit has shown that it is possible for a country to leave the euro even against its will, if the ECB rejects its public debt as collateral in RO. However, this does not prove that the EZ is experiencing a BoP crisis: this would occur after returning to its former currency.

Lastly, we have offered some evidence that the responsibility of external debt should not fall on current-account deficits but on the financial institutions that became too big. The cause of the crisis in the EZ periphery was a combination of an unsustainable debt-led growth pattern and the lack of a lender of last resort to governments once those economies derailed.

With $\mathrm{T} 2$, there is just one currency. This means that if foreign exchange markets did not exist, there could not be a BoP crisis, so that the cause of the crisis should be found elsewhere. We believe that a good candidate for the cause is bad bank behaviour, granting too much credit, which dragged down national governments. And due to failures in the design of the monetary union, the ECB has found too many obstacles for playing the role of lender of last resort to governments and also for assuming its role in the resolution of a bank crisis. There is one point of agreement in these two views. If further integration is not possible, we should seriously consider abandoning the euro.

\section{REFERENCES}

Al-Safar, Y., W. Ridinger and S. Whitaker (2013), 'The role of external balance sheets in the financial crisis', Financial Stability Paper No 24, Bank of England, October.

Baldwin, R. and F. Giavazzi (2015), 'Towards a consensus on the causes of the EZ Crisis', Voxeu.org, 7 September.

Barba, A. and G. de Vivo (2013), 'Flawed currency areas and viable currency areas: external imbalances and public finance in the time of the euro', Contributions to Political Economy, 32(1), 73-96. 
Bellofiore, R., F. Garibaldo and M. Mortagua (2015), 'A credit-money and structural perspective on the European crisis: why exiting the euro is the answer to the wrong question', Review of Keynesian Economics, 3(4), 471-490.

Bindseil, U. (2004), Monetary Policy Implementation: Theory, Past and Present, Oxford: Oxford University Press.

Bindseil, U. and P. König (2012), 'TARGET2 and the European sovereign debt crisis', Kredit und Kapital, 45(2), 135-174.

Borio, C. and P. Disyatat (2011), 'Global imbalances and the financial crisis: link or no link?' BIS Working Papers 346, May.

Borio, C. and P. Disyatat (2015), 'Capital flows and the current account: taking financing (more) seriously', BIS Working Papers 525, October.

Broner, F., T. Didier, A. Erce and S.L. Schmukler (2013), 'Gross capital flows: dynamics and crises', Journal of Monetary Economics, 60, 113-133.

Brunnermeier, M., J. De Gregorio, B. Eichengreen, M. El-Erian, A. Fraga, T. Ito, P.R. Lane, J. Pisani-Ferry, E. Prasad, R. Rajan, M. Ramos, H. Rey, D. Rodrik, K. Rogoff, H.S. Shin, A. Velasco, B. Weder di Mauro and Y. Yu (2012), 'Banks and cross-border capital flows: policy challenges and regulatory responses', Committee on International Economic Policy and Reform, Brookings, Washington, DC, September.

Cesaratto, S. (2013), 'The implications of TARGET2 in the European balance of payments crisis and beyond', European Journal of Economics and Economic Policy: Intervention, 10(3), 359-382.

Cesaratto, S. (2015a), 'Balance of payments or monetary sovereignty? In search of the EMU's original sin - comments on Marc Lavoie's The Eurozone: Similarities to and Differences from Keynes's Plan', International Journal of Political Economy, 44(2), 142-156.

Cesaratto, S. (2015b), 'Alternative interpretation of a stateless currency crisis', Cambridge Journal of Economics, 41(4), 977-998.

Cesaratto, S. (2015c), 'Unlimited targets? Some pointers', blog entry, 1 October, available at: http://nakedkeynesianism.blogspot.it/2015/10/unlimited-targets-some-pointers.html (accessed 8 February 2016).

De Grauwe, P. (2013), 'Design failures in the eurozone: can they be fixed?', LEQS Paper no 57/2013, London School of Economics and Political Science.

De Grauwe, P. and Y. Ji (2013), 'Panic-driven austerity in the Eurozone and its implications', Voxeu.org, 21 February.

Dodig, N. and H. Herr (2014), 'Current account imbalances in the EMU: an assessment of official policy responses', Panoeconomicus, 62(2, Special Issue), 193-216.

Draghi, M. (2012), 'Verbatim of the remarks made by Mario Draghi', Speech at the Global Investment Conference, London, 26 July, available at: www.ecb.int (accessed 8 February 2016).

Dullien, S. and M. Schieritz (2012), 'German savers should applaud the growing TARGET balances', Voxeu.org, 7 May.

ECB (2007), 'The EU arrangements for financial crisis management', Monthly Bulletin, February, $73-84$.

ECB (2008), 'Technical specifications for the temporary expansion of the collateral framework', Press release, 17 October (accessed 8 February 2016).

ECB (2011), Guidelines of the European Central Bank of 20 September 2011 on Monetary Policy Instruments and Procedures of the Eurosystem, Official Journal, No L 331, 14 December.

ECB (2015a), 'Eligibility of Greek bonds used as collateral in Eurosystem monetary policy operations', Press release, 4 February (accessed 8 February 2016).

ECB (2015b), 'ELA to Greek banks maintained at its current level', Press release, 28 June (accessed 8 February 2016).

Economist, The (2015), 'The Economist explains: what emergency liquidity assistance means', 8 February.

European Council (2015), 'Eurogroup statement on Greece', Press release, 17 July (accessed 8 February 2016).

Febrero, E. and F. Bermejo (2013), 'Spain during the Great Recession: teetering on the brink of collapse', in Ó. Dejuán, E. Febrero and J. Uxó (eds), Post-Keynesian Views of the Crisis and its Remedies, London: Routledge, pp. 266-293. 
Febrero, E., J. Uxó and Ó. Dejuán (2015), 'The ECB during the Financial Crisis. Not so unconventional!', Metroeconomica, 66(4), 715-739.

Frenkel, R. (2012), 'What have the crises in emerging markets and the Euro Zone in common and what differentiates them?', Iniciativa para la transparencia financiera, available at: www.itf.org.ar (accessed 8 February 2016).

Garber, P. (2010), 'The mechanics of intra euro capital flight', Global Markets Research: Macro, Deutsche Bank Special Report, 10 December.

Geithner, T. (2014), Stress Test: Reflections on Financial Crises, London: Random House Business Books.

Graziani, A. (2003), The Monetary Theory of Production, Cambridge, UK: Cambridge University Press.

Gros, D. (2015), 'The Eurozone crisis as a sudden stop: it is the foreign debt which matters', Voxeu.org, 7 September.

Hein, E. (2013), 'Finance-dominated capitalism, re-distribution and the financial and economic crises: a European perspective', in Ó. Dejuán, E. Febrero and J. Uxó (eds), Post-Keynesian Views of the Crisis and its Remedies, London: Routledge, pp. 15-45.

Heise, A. (2015), 'Euro or not Euro - that is not the question! Economic well-being and the fate of the Economic and Monetary Union', Review of Keynesian Economics, 4, 443-456.

Janus, T. and D. Riera-Crichton (2016), 'Banking crises, external crises and gross capital flows', Globalization and Monetary Policy Institute Working Paper No 273, Federal Reserve Bank of Dallas, June.

Johnson, K. (2009), 'Gross or net international financial flows: understanding the financial crisis', Council on Foreign Relations, Center for Geoeconomic Studies, Working paper, July.

Keister, T. and J. McAndrews (2009), 'Why are banks holding so many excess reserves?', Staff Report no 380, Federal Reserve Bank of New York, July.

Kelton, S. and L.R. Wray (2009), 'Can Euroland survive?', Public Policy Brief, no 106, The Levy Institute of Bard College.

Keynes, J.M. (1936), The General Theory of Employment, Interest and Money, New York: Harcourt and Brace.

Keynes, J.M. (1942 [1969]), 'Proposal for an International Clearing Union', in J.K. Horsfield (ed.), The International Monetary Fund 1946-1965, vol. 3, Washington, DC: International Monetary Fund, pp. 946-965.

Krugman, P. (2012), 'European crisis realities', The New York Times, 25 February.

Lane, P.R. (2014), 'International financial flows and the Irish crisis', CES-ifo Forum 2, June, pp. $14-19$.

Lavoie, M. (2014), Post-Keynesian Economics: New Foundations, Cheltenham, UK and Northampton, MA: Edward Elgar.

Lavoie, M. (2015a), 'The Eurozone: similarities to and differences from Keynes's plan', International Journal of Political Economy, 44(1), 3-17.

Lavoie, M. (2015b), 'The Eurozone crisis: a balance-of-payments problem or a crisis due to a flawed monetary design?', International Journal of Political Economy, 44(2), 157-160.

Mian, A. and A. Sufi (2014), House of Debt: How They (and You) Caused the Great Recession, and How We Can Prevent It from Happening Again, Chicago: The University of Chicago Press.

Moore, B. (1988), Horizontalists and Verticalists: The Macroeconomics of Credit Money, Cambridge, UK: Cambridge University Press.

Obstfeld, M. (2012), 'Does the current account still matter?', Richard T. Ely Lecture, American Economic Association meeting, American Economic Review, Papers and Proceedings, 102(3), $1-23$.

Parguez, A. (1999), 'The expected failure of the European economic and monetary union: a false money against the real economy', Eastern Economic Journal, 25(1), 63-76.

Purificato, F. and C. Astarita (2015), 'TARGET2 imbalances and the ECB as lender of last resort', International Journal of Financial Studies, 3, 482-509.

Rey, H. (2013), 'Dilemma not trilemma: the global financial cycle and monetary policy independence', Paper presented at the Jackson Hole Symposium, August. 
Schularik, M. and A. Taylor (2012), 'Credit booms gone bust: monetary policy, leverage cycles and financial crises, 1870-2008', American Economic Review, 102(2), 1029-1061.

Shin, H.S. (2012), 'Banking glut and loan risk premium', Mundell Fleming Lecture, IMF Review 60.

Sinn, H.W. (2011), 'The ECB's secret bailout strategy', Project Syndicate, 29 April.

Spiegel (2011), 'Preparing for the worst: the high price for abandoning the Euro', 29 November, available at: http://www.spiegel.de/international/europe/preparing-for-the-worst-the-highprice-of-abandoning-the-euro-a-800700.html (accessed 6 November 2016).

Trichet, J.C. (2013), 'Unconventional monetary policy measures: principles-conditions-raison d'être', International Journal of Central Banking, 9(S1), 229-250.

Turner, A. (2016), Between Debt and the Devil: Money, Credit and Fixing Global Finance, Princeton, NJ: Princeton University Press.

Vernengo, M. (2015), 'Greece on the verge', blog entry, 30 June, available at: nakedkeynesianism.blogspot.com.es/2015/06/greece-on-verge.html (accessed 8 February 2016).

Whelan, K. (2013), 'Ireland's economic crisis: the good, the bad and the ugly', Paper presented at the Bank of Greece conference on the Euro Crisis, Athens, May.

Wray, L.R. (2009), 'The rise and fall of money manager capitalism: a Minskian approach', Cambridge Journal of Economics, 33, 807-828.

Wray, L.R. (2012a), 'MMT and the euro: are current account imbalances to blame for the Euro disaster? Part 1', blog entry, economonitor.com, 12 July (accessed 8 February 2016).

Wray, L.R. (2012b), 'Current account imbalances and the Euro Crisis Part 12', blog entry, economonitor.com, 16 July (accessed 8 February 2016).

Wray, L.R. (2012c), 'Imbalances, what imbalances? A dissenting view', in H. Herr, T. Niechoj, C. Thomasberger, A. Truger and T. van Treeck (eds), From Crisis to Growth? The Challenge of Imbalances and Debt, Marburg: Metropolis, pp. 123-144.

Wyplosz, C. (2015), 'Grexit: the staggering cost of central bank dependence', Voxeu.org, 29 June. 